\title{
Pankreatik duktal adenokarsinomlar ve ampüller bölge adenokarsinomlarında HSF-1 ve P53 ekspresyonlarının prognostik faktörlerle ilişkisi
}

\section{Relationship of HSF-1 and P53 expressions to prognostic factors in pancreatic ductal adenocarcinomas and ampullary region adenocarcinomas}

Mehmet ZENGIN ${ }^{1 *}$, Nevra DURSUN², Hüsniye Esra PAŞAOĞLU³ ${ }^{3}$ Oğuz KOÇ ${ }^{4}$

\author{
${ }^{1}$ Yozgat Devlet Hastanesi, Patoloji Kliniği, Yozgat \\ 2 İstanbul Eğitim ve Araştırma Hastanesi, Patoloji Kliniği, İstanbul \\ ${ }^{3}$ Bağcılar Eğitim ve Araştırma Hastanesi, Patoloji Kliniği, İstanbul \\ ${ }^{4}$ Acıbadem Aile Hastanesi, Genel Cerrahi Kliniği, İstanbul, TÜRKIYE
}

\section{öz}

Amaç: Periampüller bölge adenokarsinomları; pankreas ve ampüller bölge tümörlerini içine alan, medikal ve cerrahi tedaviye dirençli ve hızlı metastatik progresyon gösteren tümörlerdir. Isı şok faktörü-1, ısı şok genlerini aktif hale getirir ve malign transformasyon ve kanser hücrelerinde çoğalmayı kolaylaştırır. P53 ise pankreatik kanserlerin \%50'sinden fazlasında mutasyona uğrayan tümör baskılayıcı bir gendir. Bu çalışmada HSF-1 ve P53 ekspresyonlarının tümör boyutu, lenf nodu metastazı, tümör evresi, tümör diferansiasyonu ve prognoz ile ilişkisi analiz edilmiştir.

Gereç ve Yöntem: İstanbul Eğitim ve Araştırma Hastanesi'nde uygulanan 69 pankreatikoduodenektomi materyali; HSF1/P53 ekpresyonu, yaş, cinsiyet, tümör lokalizasyonu, tümör boyutu, tümör evresi, tümörün diferansiasyonu, lenf nodu metastazı varlığı ve prognoz açısından yeniden araştırıldı.

Bulgular: Çalışmamızda, \%10'un üzerinde boyanma görülen olgularda, büyük tümör boyutu, ileri evre tümör varlığı, yüksek dereceli tümör varlığı, pozitif lenf düğümü ve kötü prognoz daha fazla oranda izlenmiştir.

Sonuçlar: Çalışmamız HSF-1 ve P53 ekspresyonlarının, özellikle yüksek dereceli periampüller bölge adenokarsinomlarının gelişiminde rol oynadığını düşündürmektedir. Ayrıca bu iki marker, az differansiye adenokarsinom tanısında diğer parametreler ile birlikte tercih edilebilir.

Anahtar Kelimeler: Periampüller bölge adenokarsinomları, pankreas, duktal adenokarsinom, ampulla, HSF-1, P53, prognostik faktörler

Corresponding Author*: Mehmet ZENGIN, MD. Yozgat Devlet Hastanesi, Patoloji Kliniği, Yozgat, TÜRKIYE

e-mail: mz1379@hotmail.com

Doi. $10.18663 / \mathrm{tjcl} .284388$

Received 08.03.2017 accepted 05.01.2017 


\title{
ABSTRACT
}

\begin{abstract}
Aim: Periampullary region adenocarcinomas, which includes pancreatic ductal adenocarcinoma and ampullary carcinoma is one of the malignant tumors with characterized by rapid metastatic progression and resistant to medical and surgical treatments. Heat shock genes are activated by heat shock factor- 1 and facilitates malignant transformation and cancer cell proliferation. P53 is a tumor suppressor gene which mutated in more than $50 \%$ of pancreatic cancers. In this study, the relation of paramaters which include tumor size, lymph node metastasis, tumor stage, tumor grade and prognosis with HSF-1 and P53 expession was analysed.
\end{abstract}

Material and Method: 69 pancreaticoduodenectomy materials which performed in the Istanbul Education and Research Hospital were researched entirely about the HSF-1/ P53 expression, age, gender, tumor location, tumor size, tumor stage, tumor grade, presence of lymph node metastasis and prognosis.

Results: In our study, tumors which stained $>10 \%$, had more percentage in large tumor size, advanced stage tumors, high grade tumors, positive lymph nodes and poor prognosis.

Conclusion: Our study suggest that HSF-1 and P53 expression plays role at carcinogenesis of especially high grade periampullary region adenocarcinomas. In addition, these two markers may be preferred in combination with other parameters, at the diagnosis of poor differentiated adenocarcinomas.

Keywords: Periampullary region adenocarcinomas, pancreas, ductal adenocarcinoma, ampullary, HSF-1, P53, prognostic parameters

\section{Giriş}

Periampüller bölge adenokarsinomları (PBA), pankreas ve ampüller bölge adenokarsinomlarını (ABA) içine alan, gelişmiş ülkelerde kansere bağlı ölüm nedenlerinde ön sıralarda yer alan ve çok hızlı sistemik yayııımı ile diğer kanserlerden farklılık gösteren tümörlerdir [1]. PBA'lar özellikle de pankratik duktal adenokarsinomlar (PDA), mortalitesi yüksek olan hastalıklardan olup dünyada kanserden ölüm nedenleri arasında beşinci, Amerika Bileşik Devletleri'nde ise dördüncü yeri tutmaktadır [2,3]. Tanı anında olguların büyük kısmında tümör organ sınırlarını aşmış ve olguların yalnzca \%20'sinde rezeksiyon mümkün olabilmektedir [4]. PBA'ların gerek sessiz ilerlemesi, gerekse tıbbi tedaviye direnç göstermesi nedeniyle, prognoz ve tedaviyi yönlendirmek için sürekli yeni alanlarda çalışmalar yapılmaktadır $[5,6]$.

Isı şok proteinleri (HSP) hücre yaşamında kritik rol oynamakta olup Isı şok proteini-1 (HSF-1) ısı şok cevabında düzenleyici ve P53 proteini ile de ilişkili olan bir faktördür $[7,8]$. Bu regülatörle çeşitli organlarda yapılan çeşitli çalışmalarda, prognostik yarar ve hedefe yönelik tedavi açısından olumlu yanıtlar bulunmuştur [8]. Literatürde PBA'larda HSF-1 ekspresyonu ile alakalı çok az sayıda çalışma mevcut olup, ileri çalışmalarla hedefe yönelik tedavilerde faydalı olabilmek için, bu çalışmayı sunduk.

\section{Gereç ve Yöntem}

Olgu Seçimi

İstanbul Eğitim ve Araştırma Hastanesi'ne 2000-2012 yılları içerisinde gelen ve parafin bloklarına ulaşılabilen 69 olgu çalışmaya dahil edildi. Bu olguların klinik, laboratuvar ve radyolojik bilgileri arşiv kayıtlarından elde edildi. Bu olgular pankreas ve ampulla olmak üzere 2 gruba ayrıldı. Her iki grup; yaş, cinsiyet, tümör lokalizasyonu, tümör boyutu, histolojik diferansiasyon, tümör evresi, lenf nodu metastazı ve prognoz açısından yeniden değerlendirildi. Saptanan bulgular ile HSF1 ve P53 arasındaki ilişki istatiksel olarak değerlendirildi.

\section{Histolojik Diferansiasyon ve Evreleme}

Olgulara ait tüm Hematoksilen\&Eozin boyalı arşiv preperatları yeniden gözden geçirildi. Gerekli görülen bloklardan tekrar kesitler alındı. Olguların tümü Dünya Sağlık Örgütü'nün 2010 egzokrin pankreas ve ampulla tümörleri sınıflama ve evreleme sistemine göre tekrar gruplandı [1].

\section{İmmünhistokimyasal Çalışma}

Tümörün özelliklerini en iyi yansıtan örneklerin rutin işlemlerden geçmiş bloklarından biri seçilerek 5 mikron kalınlığında kesitler alındı. İmmünhistokimyasal (IHK) incelemede HSF-1 [E-4: sc-17757 (1:30), Mouse monoclonal, cat no: Lot-A0411, Santa Cruz Biotechnology, USA] ve P53 
[Ab-5 (1:200), Mouse monoclonal, cat no: MS-186-P1, Thermo Scieentific, USA] antikorları kullanıldı. Çalışma öncesinde pozitif kontrol olarak HSF-1 için memeye ait invazivduktal karsinom dokusu, P53 için ise kolon adenokarsinomu dokusu kullanıldı. Pozitif kontrol için seçilen ancak primer antikorun damlatılmadığı örnekler ise negatif kontrol olarak kabul edildi. IHK'sal çalışma streptovidin/avidin/biotin yöntemiyle yapıldı. Boyamada Leica Bond Max tam otomatik immünhistokiyasal boyama cihazı kullanıldı.

\section{İmmünohistokimyasal Skorlama}

IHK'sal incelemede HSF-1 ve P53 için nükleer boyanma pozitif olarak kabul edildi. Her tümörde en az 1000 tümör nukleusu sayılmış olup semikantitatif ve subjektif derecelendirme sistemi kullanılarak tümör hücrelerindeki boyanma varlığı, boyanma şiddeti ve boyanmanın yaygınlığı incelendi. Boyanma yaygınlığı semikantitatif olarak aşağıdaki gibi gruplandı:

0: Boyanma yok veya tümörün \%5'inden az

1: Boyanma yaygınlığı \%5-10 arası.

2: Boyanmanın yaygınlığı \%10- 100 arası

Boyanma şiddeti subjektif olarak zayıf, orta ve kuvvetli olarak gruplandı. İstatistiksel değerlendirme sırasında grup 0 ve grup 1 olguları birleştirildi.

\section{Istatistiksel Değerlendirme}

Verilerin tanımlayıcı istatistiklerinde, oran ve frekans değerleri kullanıldı. Niteliksel verilerin analizinde Ki-Kare test, sağlanamadığında ise Fischer test kullanıldı. Uyum analizinde Kappa uyum testi kullanıldı. Sağ kalım analizinde KaplanMeier sağ kalım analizi kullanıldı. Analizlerde SPSS 21.0 programı kullanıldı. Veri sunumu; sayı, yüzde, en küçük, en büyük değerler kullanılarak yapıldı. Anlamlılık sınırı $\mathrm{P}<0,05$ olarak kabul edildi.

\section{Bulgular}

Çalışmaya alınan olguların 50'si $(\% 72,4)$ erkek, 19'u $(\% 27,6)$ kadın olup, ortalama yaş 61,8 (en küçük 36, en büyük 88) olarak saptanmıştır. Olguların yaş dağılımı incelendiğinde, 34'ünün (\%49,2) 51-80 yaş aralığında olduğu görülmüştür.

\section{Tümör lokalizasyonu}

Tümör olguların 33'ünde (\%47.8) pankreas, 36'sında (\%52.2) ampulla yerleşimlidir.

\section{Tümör boyutu}

Olgulara ait materyallerde tümörler en küçük $1 \mathrm{~cm}$, en büyük $7 \mathrm{~cm}$ çapa sahip olup, olguların 24'ünde $(\% 34,7)$ tümör çapı 2 cm ve altında, 45'inde $(\% 65,2) 2$ cm'nin üstünde saptanmıştır.

\section{Pozitif lenf nodu}

Olguların 38'inde $(\% 55,1)$ bölgesel lenf nodülü metastazı izlenmiş, $31(\% 44,9)$ olguda metastaz saptanmamıştır. Olgularda en az 1, en fazla 13 adet lenf nodu metastazı izlenmiştir.

\section{Evre}

Olguların 21'i $(\% 31,0)$ PT2, 39'u (\%56,0) PT3, 9’u (\%13) ise PT4 olarak tespit edilmiştir.

\section{Prognoz}

Olguların 33'ünün $(\% 68,7)$ öldüğü, 15 'inin ise $(\% 31,2)$ yaşadığı görüldü. Ortalama sağ kalım süresi 50,5 ay (en az 6, en çok 83 ay) olarak bulunmuştur.

\section{Histolojik Diferansiasyon}

Olguların 6'sında $(\% 8,7)$ tümör iyi diferansiye, 54'ünde $(\% 78,2)$ tümör orta diferansiye, 9'unda $(\% 13,1)$ az diferansiye olarak değerlendirilmiştir.

\section{İmmünhistokimyasal bulgular}

\section{Genel Bulgular}

HSF-1: 42 olguda $(\% 60,8)$ HSF-1 ile boyanma izlenmezken; $27(\% 39,1)$ olgu HSF-1 ile pozitif boyanmıştır. Pozitif olguların 23'ünde $(\% 85,1)$, boyanma yaygınlığı \%10'nun üzerinde saptanmış olup (Resim 1-3); 4 olguda (\%14,9) \%10'nun altında saptanmıştır (Resim 2-3). P53: Olguların 12'sinde (\%17,3) P53 ile boyanma izlenmezken; 57'sinde $(\% 82,6)$ boyanma saptanmıştır. Pozitif olguların 51'inde $(\% 89,4)$ boyanma yaygınlığı \%10'nun üzerinde saptanmıştır (Resim 4-5). 6 olguda $(\% 8,6)$ ise boyanma yaygınlığı \%10'nun altında saptanmıştır.


Resim 1. PDA'larda HSF-1 ile kuvvetli ve $\% 10^{\prime}$ un üzerinde nükleer pozitif boyanma
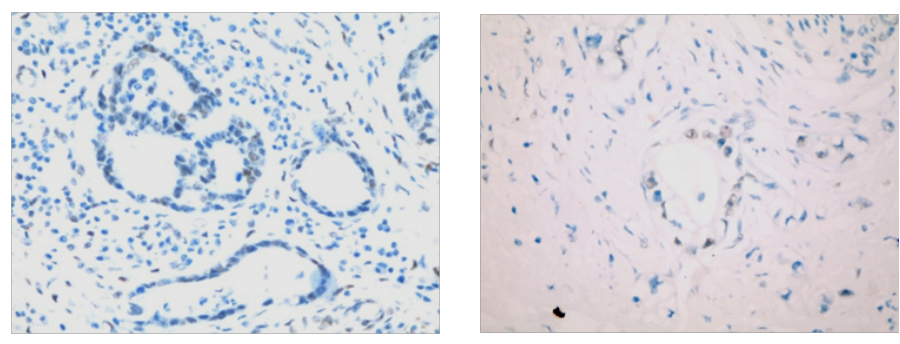

Resim 2. PDA'larda HSF-1 ile zayıf ve $\% 10$ 'un altında nükleer pozitif boyanma 

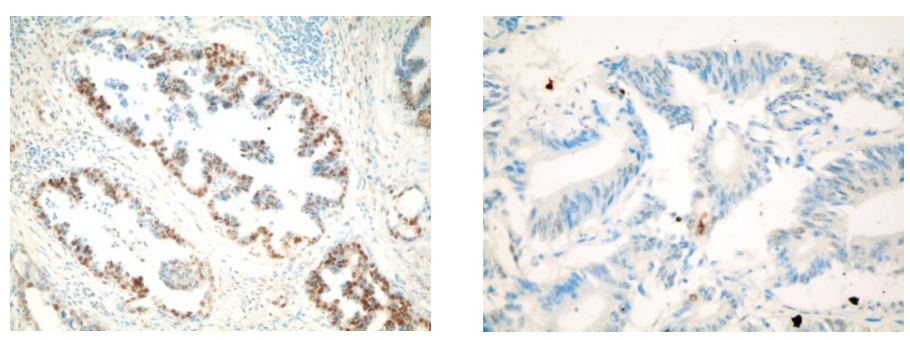

Resim 3. ABA'larda HSF-1 ile nükleer pozitif boyanma (sağda \%10'un üzerinde ve kuvvetli, solda \%10'un altında ve zayıf)

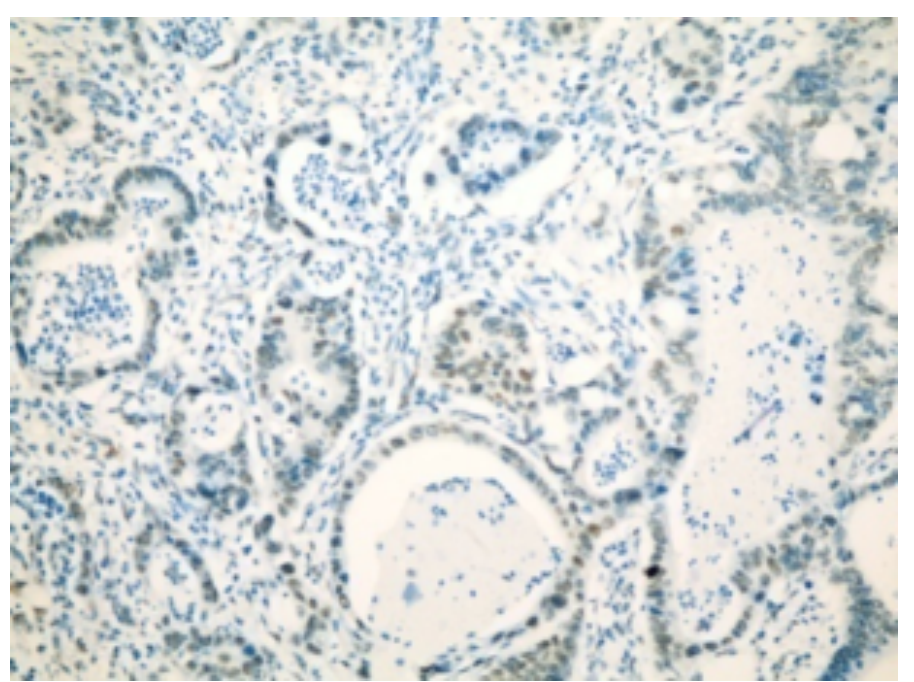

Resim 4. PDA'larda P53 ile \%10'un üzerinde kuvvetli nükleer pozitif boyanma

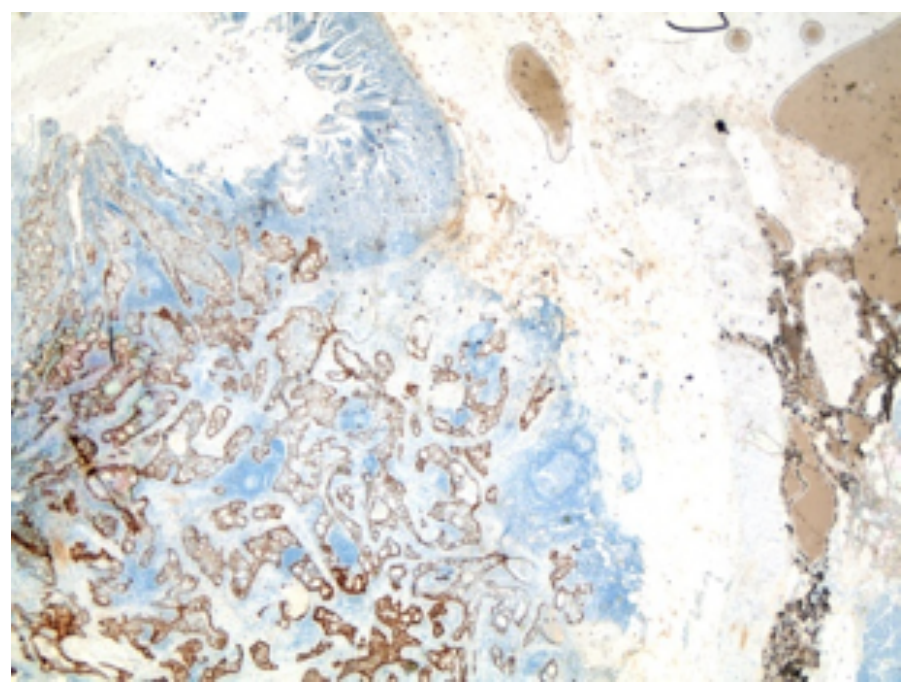

Resim 5. ABA'larda P53 ile \%10'un üzerinde kuvvetli nükleer pozitif boyanma

\section{Tümör boyutu}

HSF-1 ve P53; boyanma yaygınlığı \%10'un altında ve \%10'un üzerinde olan hastalar arasında, istatistiksel olarak anlamlı ( $P$ $>0,05$ ) fark görülmemiştir (Şekil 1-2). Ancak \%10'un üstünde HSF-1 boyanma yaygınlığı olan olguların \%78'inde; \%10'un üzerinde P53 boyanma yaygınlığı olan olguların \%88'inde tümör çapı $2 \mathrm{~cm}$ ve üstündedir.

\section{Pozitif lenf nodu}

HSF-1 ve P53; boyanma yaygınlığı \%10'un altında ve \%10'un üzerinde olan hastalar arasında, istatistiksel olarak anlamlı ( $P$ $>0,05$ ) fark görülmemiştir (Şekil 1-2). Ancak \%10'un üstünde HSF-1 boyanma yaygınlığı olan olguların \%70'inde; \%10'un üzerinde P53 boyanma yaygınlığı olan olguların \%50'sinde lenf nodu pozitifliği saptanmıştır.

\section{Evre}

HSF-1 ve P53; boyanma yaygınlığı \%10'un altında ve \%10'un üzerinde olan hastalar arasında, evre dağılımı açısından istatistiksel olarak anlamlı $(P>0,05)$ fark görülmemiştir (Şekil1-2). Ancak \%10'un üstünde HSF-1 boyanma yaygınlığı olan olguların \%50'sinde; \%10'un üzerinde P53 boyanma yaygınlığı olan olguların \%70'inde PT3 ve PT4 tümör saptanmıştır.

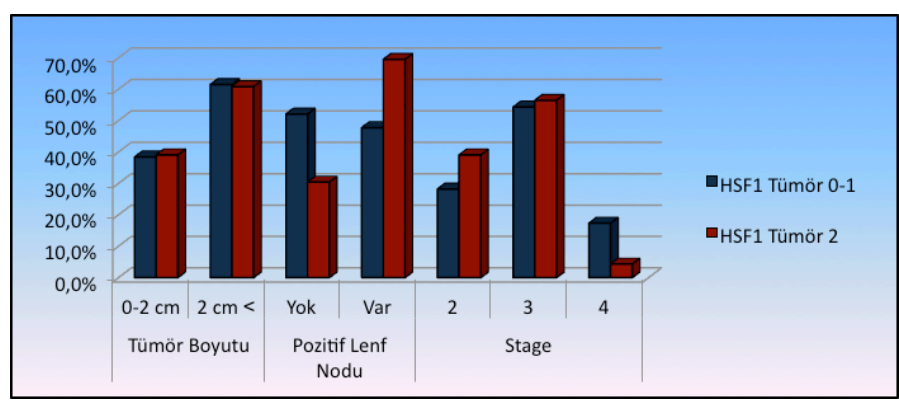

Şekil 1. HSF-1 ileTümör boyutu/pozitiflenf nodu/stage arasındaki istatiksel ilişki (0-1: \%10'un altında; 2: \%10'un üzerinde)

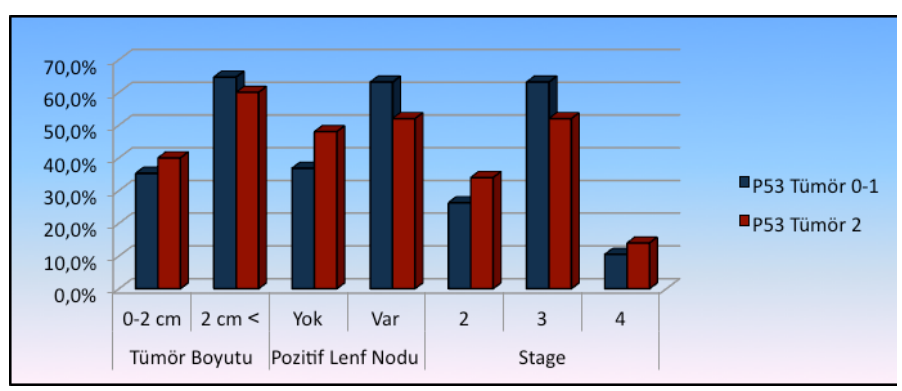

Şekil 2. P53 ile tümör boyutu/pozitif lenf nodu/stage arasındaki istatiksel ilişki (0-1:\%10'un altında; 2: \%10'un üzerinde)

\section{Prognoz}

HSF-1 ve P53; boyanma yaygınlığı \%10'un altında ve \%10'un üzerinde olan hastalar arasında, prognoz dağılımı açısından istatistiksel olarak anlamlı $(P>0,05)$ fark görülmemiştir (Şekil 3-4). Ancak 5 yıllık takip sürecinde, \%10'un üstünde HSF-1 boyanma yaygınlığı olan olguların \%82'sinin; \%10'un üstünde P53 yaygınlığı olan olguların ise \%76'sının öldüğü saptanmıştır. 


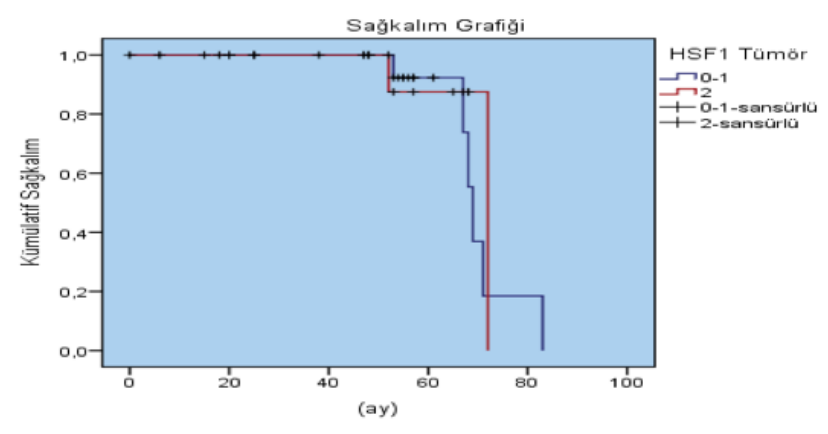

Şekil 3. HSF-1 ile prognozun arasındaki istatiksel ilişki (0-1: \%10'un altında; 2: \%10'un üzerinde)

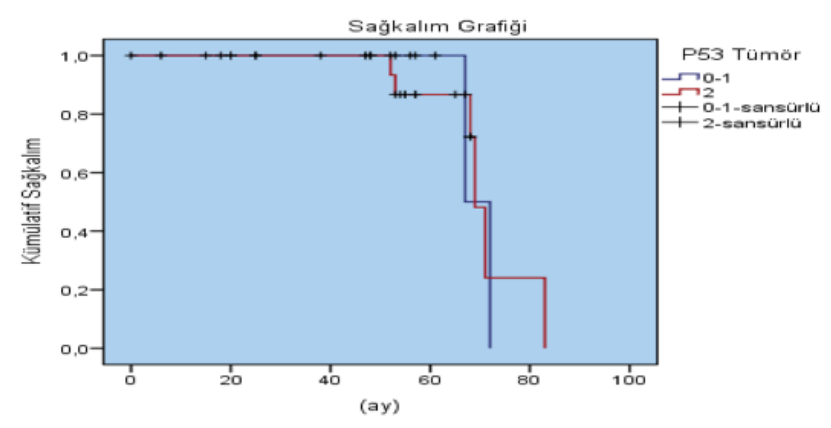

Şekil 4. P53 ile prognozun istatiksel ilişkisi (0-1: \%10'un altında; 2: \%10'un üzerinde)

\section{Derece}

HSF-1 ve P53; boyanma yaygınlığı \%10'un altında ve \%10'un üzerinde olan hastalar arasında, grade dağılımı açısından istatistiksel olarak anlamlı (P > 0,05) fark görülmemiştir. Ancak \%10'un üstünde HSF-1 pozitifliği olan olguların \%90'ında; \%10'un üzerinde P53 boyanma yaygınlığı olan olguların \%88'inde orta ve az diferansiye tümör saptanmıştır.

\section{Tartışma}

Periampüller bölge denilen ampulla çevresindeki 2 cm'lik küçük bir alan, temel olarak pankreas ve ampulla olmak üzere iki anatomik yapıdan oluşmakta olup bu bölgeden çıkan kanserler, PDA ve ABA olmak üzere iki ana grubta sınıflanmaktadır [1]. PDA yüksek mortaliteye sahip olan bir hastalık olup kansere bağlı ölüm nedenlerinde ön sıralarda yer almaktadır [2,3]. Etyolojisinde yaşın yanı sıra, sigara, tip 2 diabetes mellitus, fazla yağ içeren beslenme, kronik pankreatit, Primer sklerozan kolanjit, herediter pankreatit, ailesel pankreas kanseri varlığı yer almaktadır [4,5].

ABA'lar seyrek görülen tümörler olup tüm sindirim sistemi kanserlerinin \%5'ini oluşturmaktadır [6]. 60-80 yaşları arasında daha sık görülmekte olup Familyal adenomatöz polipozis ile ilişkili hastalarda daha erken yaşlarda gözükmektedir [6]. HSF-
1, sıcaklık şoku, oksidatif stres ya da aminoasit analogları gibi tüm stres koşullarında hücresel tepkide önemli rol oynayan bir transkripsiyon faktörüdür $[7,8]$.

PBA'lar tanı anında sıklıkla tümör boyutu 2 cm'den büyük olup, az diferansiye ve ileri evre tümörler olarak karşımıza çıkmaktadır. Bu bölge kanserlerinin \%80-85'i pankreas, \%15-25'i ampulla vateri kökenli olup erkeklerde daha sık görülmektedir [9]. PBA'ların erkeklerde daha sık rastlanmakta olup görülme sıklığı yaşla birlikte giderek artmaktadır. Johnson CD ve ark. [10] yaptığı çalışmada olguların yaş ortalaması 61,9, Filiz $\mathrm{G}$ ve ark. [11] yaptığı çalışmada ortalama yaş 60,6 yıl, Nuzzo G ve ark. [12] yaptığı çalışmada ise ortalama yaşı 67,4 yıl olarak bildirmiştir. Çalışmamızda ortalama yaş 61,8 olarak saptanmış olup, olguların \%49,2'sinin 51-80 yaş aralığında olduğu görülmüştür.

Çalışmamızda, cinsiyet, yaş, tümör boyutu, tümör evresi, tümör derecesi ile ilişkili bulgularımız literatür bilgileri ile benzerlik göstermekle beraber lenf nodu metastazı ve prognoz sonuçlarımız hafif düşük, ampulla tümörleri ise hafif yüksek oranda oranda izlenmiştir. Bu bulgunun olgu sayısının azlığına, hasta seçimine ve pankretik duktal adenokarsimomlarının çoğunlukla inoperabl olmasına bağlı olduğu düşünülmüşür.

Sıcaklık organizmalardaki fizyolojik fonksiyonları etkileyen en önemli çevresel etmenlerden biridir [13]. Isı şok genlerinin transkripsiyonunun başlaması giderek artan stres sinyallerine karşı bir yanıttır [13,14]. Sıcaklık şoku yanıtının gen düzenlenmesi üzerine yapılan araştırmalar sonucunda üç tip sıcaklık şok faktör geni olduğu belirlenmiştir [14,15]. Ancak memelilerde HSF-1 strese yanıtta dominant faktördür [16]. Çalışmalar HSF-1'in etkilerinin çok komplike olduğunu ve malignitenin kontrolü, tümör büyümesi vs. gibi geniş bir etkiye sahip olduğunu göstermiştir $[17,18]$. Ayrıca birçok kanser türünde de (epidermoid karsinom, multiple myelom, lenfoma vs.) HSF-1 seviyesinin yüksek olduğu tespit edilmiştir [19-21]. Bununla beraber HSF-1, P53 proteinin düzenlenmesinde de rol oynamakta olup, HSF-1 eksikliğine sahip hücrelerde P53'ün biriktiği ve HSF-1'in P53 aracılı hücre döngüsünü duraklatmada önemli rol oynadığı ortaya konmuştur [22].

PDA'larda tümör gelişimine katkı sağlayan mutasyonlar belli bir sıra ile ilerlemektedir [23]. PDA'ların oluşumu ve ilerlemesi ile ilgili önerilen modellerde, PanIN evrelendirmesi dikkate alınmakta olup, P53 mutasyonları PanIN-2/3 gibi daha geç evrelerde ortaya çıkmaktadır $[23,24]$. PDA'ların gelişimi ve ilerlemesinde, birçok yolakta rol alması nedeniyle, P53 aracılı hücre döngüsü düzenlenmesinin önemli olduğu görülmektedir [24]. 
HSF-1/P53-Tümör boyutu: PBA'lar sıklıkla 2 cm'den büyük tümörler olarak karşımıza çıkmakta olup tümör çapının sağ kalıma etkisini araştıran pek çok çalışma bulunmaktadır [25]. PDA'ların prognostik faktörler ile ilişkilerinin değerlendirildiği bir derlemede 36 makale yer almakta olup 29'unda büyük tümör boyutunun artmasının sağ kalıma negatif etkisi olduğu belirtilmektedir [26]. Yine aynı çalışmada tümör çapının, bölgesel lenf nodu metastazı ve cerrahi sınır pozitifliğinden sonra sağ kalımda en etkili parametre olduğu belirtilmiştir [26]. Çalışmamızda 2 cm'den büyük tümör varlığı yüksek oranda $(\% 78,2)$ izlenmiştir. Ayrıca \%10'un üstünde HSF-1 ve P53 boyanma yaygınlığı olan olgularda, $2 \mathrm{~cm}$ ve üstünde tümör boyutu (\%78-88) daha yüksek oranda saptanmıştır.

PBA'lar sıklıkla orta ve az diferansiye tümörler olarak karşımıza çıkmakta olup; az diferansiye tümörler lenfovasküler invazyon ve bölgesel lenf nodu metastazını daha sık yapması nedeniyle, kötü prognozla ilişkili olarak bulunmaktadır $[27,28]$. Michelassi ve arkadaşlarının yaptıkları çalışmada; olguların \% 50'si iyi diferansiye, \%34,1'i orta diferansiye, \%15,2'si ise az diferansiye olarak izlenmiştir [28]. Çalışmamızda da orta ve az diferansiye tümörler yüksek oranda $(\% 91,3)$ izlenmiştir. Ayrıca \%10'un üstünde HSF-1 ve P53 pozitifliği olan olgularda, orta-az diferansiye tümör daha yüksek oranda izlenmiştir (\%90-88).

PBA'lar çoğunlukla tanı anında lenf nodu metastazı yapmış tümörler olarak karşımıza çıkmaktadır [29]. Birçok çalışmada PDA'larda lenf nodu metastazının sağ kalımda etkili olduğu bildirilmektedir [29,30]. Riediger H ve ark. [31] yaptığı çalışmada, bölgesel lenf nodu metastazının, sağ kalıma etkili en önemli parametre olduğu bildirilmektedir. Çalışmamızda lenf nodu metastazındaki yükseklik belirgin değildir $(\% 55,1)$. Ancak \%10'un üstünde HSF-1 ve P53 pozitifliği olan olgularda, lenf nodu pozitifliği HSF-1 ile daha yüksek oranda (\%72), P53 ile ise benzer oranda (\%50) izlenmiştir.

Hem PDA'lar hem de ABA'larda lokal yayılım, TNM sınıflamasına göre tümörün evresinin ilerletmektedir [32]. Her iki bölge karsinomlarıda; peripankreatik yağ dokusu, duodenum kasları ve mukozasına doğru lokal yayılım gösterebilmektedir [32,33]. Çalışmamızda da ileri evre tümör varlığı yüksek oranda (\%69) izlenmiştir. Ayrıca HSF-1 ve P53 ile boyanma yaygınlığı \%10'un üzerinde olan olgularda PT3-PT4 tümör varlığı; HSF-1 ile daha yüksek oranda (\%70), P53 ile ise benzer oranda (\%50) izlenmiştir. PDA'lı olgularda ortalama yaşam süresi 6-10 ay olup, beş yıllık sağ kalım \%4'tür. ABA'lar ise PDA'ya göre daha iyi prognoza sahip olup 5 yıllık yaşam \%30-\%60 olarak bildirilmektedir $[32,33]$. PDA'larda rezeksiyon uygulanan olgularda bile bu oran \%20'nin altında olup rezeke edilemeyen tümörlerde ise ortalama yaşam süresi 3-5 aydır [33]. Çalışmamızda mortalitedeki yükseklik belirgin değildir (\%68,7). Ancak \%10'un üstünde HSF-1 ve P53 pozitifliği olan olgularda, mortalite (\%82-76) yüksek oranda saptanmıştır. Çalışmamızda HSF-1/P53 ile \%10'un üzerinde boyanma görülen olgularda; büyük tümör boyutu, pozitif lenf düğümü varlığı, ileri evre tümör varlığı, yüksek dereceli tümör varlığı ve düşük prognoz daha fazla oranda izlenmiştir. Sonuç olarak yapılan birçok çalışmaya rağmen pankreas kanserlerinde prognoz bakımında gelişmeler sınırlı olup, halen çözülmeyi bekleyen birçok soru mevcuttur. Bulgularımız HSF-1 ve P53'ün özellikle az diferansiyasyon ile ilişkili olduğunu düşündürmüş olup, bu moleküllerin mevcut tedavilere katkıda bulunma ve hedefe yönelik tedavileri geliştirmek için yüksek potansiyele sahip olduğunu düşünüyoruz. Bu moleküller üzerinde daha geniş çalışmalara ihtiyaç vardır.

\section{Maddi Destek ve Çıkar İlişkisi}

Çalışmayı maddi olarak destekleyen kişi/kuruluş yoktur ve yazarların çıkara dayalı bir ilişkisi yoktur.

\section{Kaynaklar}

1. World health organization classification of tumours the digestive system. 4th edition. Ed: Bosman T, Carneiro F, Hruban RH, Theise ND. IARC Press Lyon, 2010.

2. Saif MW. Pancreatic cancer: Is this bleak landscape finally changing? Highlights from the 43rd ASCO Annual Meeting. Chicago, IL, USA 2007; 8: 365-73.

3. Raimondi S, Lowenfels AB, Morselli AM, Maisonneuve P, Pezzilli R. Pancreatic cancer in chronic pancreatitis; aetiology, incidence, and early detection. Best Pract Res Clin Gastroenterol 2010; 24: 349-58.

4. Löhr M, Klöppel G, Maisonneuve P, Lowenfels $A B$, Lüttges J. Frequency of K-ras mutations in pancreatic intraductal neoplasias associated with pancreatic ductal adenocarcinoma and chronic pancreatitis: A meta analysis. Neoplasia 2005; 7; 17-23.

5. Trimbath JD, Griffin C, Romans K, Giardiello FM. Attenuated Familial adenomatous polyposis as ampullary. Gut 2003; 52: 903-4.

6. Balanchandran P, Sikora SS, Kapoor S, et al. Long-term survival and recurrence patterns in ampullary cancer. Pancreas 2006; 32: 390-5.

7. Hanh JS, Hu Z, Thiele DJ, lyer VR. Genome wide analysis of the biology of stres responses through heat shock transcription factor. Mol Cell Biol 2004; 24:5 2549-56. 
8. Dudeja V, Chugh RK, Sangwan V, et al. Prosurvival role of Heat shock factor-1 in the pathogenesis of pancreatobiliary tumors. Am J Gastrointest Liver Physiol 2011; 300; G948-55.

9. Popovici A, Popescu I, lonescu MI, et al. The periampullary carcinoma. Clinical and therapeutic alternatives. Chirurgia (Bucur) 2000; 95: 407-24.

10. Filiz G, Yerci O, Adim SB, et al. Periampullary carcinomas. Hepatogastroenterology 2007; 54: 1247-49.

11. Johnson CD, Özmen MM. Pankreas kanseri. Temel Cerrahi, Sayek I (Ed), 3. baskı, Ankara, Güneş Kitabevi 2004: 1429-36.

12. Nuzzo G, Clemente G, Cadeddu F, Giovannini I. Palliation of unresectable periampullary neoplasms: Surgical versus nonsurgical approach. Hepatogastroenterol 2004; 51: 1282-5.

13. Banerji SS, Berg $L$ and Morimoto R. Transcriptional and post transcriptional regulation of avian HSP-70 gene expression. Biol Chem. 1986; 261: 15740-5.

14. Nakai A, Morimoto Rl. Characterization of a novel chicken Heat shock transcription factor, HSF-3, suggests a new regulatory pathway. Mol Cell Biol 1993; 13:1983-97.

15. Morimoto Rl. Regulation of the heat shock transcriptional response: Cross talk between a family of heat shock factors, molecular chaperones, and negative regulators. Genes Dev 1998; 12: 3788-96.

16. Dai $C$, Whitesell $L$, Rogers $A B$, Lindquist $S$. Haet shock factor 1 is a powerful multifaceted modifier of cacinogenesis. Cell 2007; 130: $1005-18$.

17. Mendillo $M L$, Santagata $S$, Koeva $M$, et al. HSF-1 drives a transcriptional program distinct from heat shock to support highly malignant human cancer. Cell 2012; 150: 549-62.

18. Calderwood SK. HSF-1, a versatile factor in tumorogenesis. Curr Mol Med 2012; 12: 1102-7.

19. Ishiwata J, Kasamatsu A, Sakuma K, et al. State of Heat shock factor-1 expression as a putative diagnostic marker for oral squamous cell carcinoma. Int J Oncol 2012; 40: 47-52.

20. Heimberger $T$, Andrulis $M$, Riedel $S$, et al. The Heat shock transcription factor 1 as a potential new therapeutic in multiple myeloma. Br J Hematology 2013; 160: 465-76.

21. Min JG, Huang L, Zimojik DB, Moskophisid D, Mivechi NF. Selective suppression of lymphomas by functional loss of HSF1 in a P53, deficient mouse model for spontaneous tumors. Oncogene 2007; 26: 5086-97.
22. Logan IR, McNeill HV, Cook S, et al. Heat shock factor 1 modulates P53 in the transcriptional response to DNA damage. Nucleic Acids Res 2009; 37: 2962-73.

23. Vimalachandran D. Genetics and prevention of pancreatic cancer. Cancer Control 2004; 11: 6-14.

24. Bardeesy N, Depinho RA. Pancreatic cancer biology and genetics. Nat Rev Cancer 2002; 2: 897-909.

25. YeoCJ,SohnTA, Cameron JL, etal. Periampullaryadenocarcinoma: analysis of 5 year survivors. Ann Surg 1998; 227: 821-31.

26. Garcea G, Dennison AR, Pattenden CJ, Neal CP, Sutton CD, Berry DB. Survival following curative resection for pancreatic ductal adenocarcinoma. A systematic review of the literature. J Pancreas 2008; 9: 99-132.

27. Takai S, Satoi S, Toyokawa H, et al. Clinicopathologic evaluation after resection for ductal adenocarcinoma of the pancreas: $A$ retrospective, single institution experience. Pancreas 2003; 26: 243-9.

28. Michelassi F, Erroi F, Dawson PJ, et al. Experience with 647 consecutive tumors of the duodenum, ampulla, head of the pancreas, and distal common bile duct. Ann Surg 1989; 210: 544-56.

29. Keleg S, Büchler P, Ludwig R, Büchler MW, Friess H. Invasion and metastasis in pancreatic cancer. Molecular Cancer 2003; 2: 1-7.

30. Ueda M, Endo I, Nakashima $M$, et al. Prognostic factors after resection of pancreatic cancer. World J Surg 2009; 33: 104-10.

31. Riediger $H, K e c k T$, Wellner $U$, et al. F. The lymph node ratio is the strongest prognostic factor after resection of pancreatic cancer. J Gastrointest Surg 2009; 13: 1337-44.

32. You DD, Lee HG, Heo JS, Choi SH, Choi DW. Prognostic factors and adjuvant chemoradiation therapy after pancreaticoduodenectomy for pancreatic Adenocarcinoma. J Gastrointest Surg 2009; 13: 1699-706.

33. Guidelines for the management of patients with pancreatic cancer periampullary and ampullary carcinomas. Pancreatic section, BSG, Gut 2005; 54: v1-16. 